\title{
Modelling corrosion of steel reinforcement in concrete (pozvano predavanje)
}

\author{
Joško Ožbolt ${ }^{1}$, Gojko Balabanić ${ }^{2}$, Filip Oršanić ${ }^{1}$ \\ ${ }^{1}$ Institute of Construction Materials, University of Stuttgart, Germany \\ ${ }^{2}$ Faculty of Civil Engineering Rijeka, University of Rijeka, Croatia
}

\begin{abstract}
In the first part of the presentation an overview of different models for modelling chloride induced corrosion of reinforcement in concrete developed in the past will be shortly presented. Subsequently, coupled 3D chemo-hygro-thermo-mechanical model for concrete will be presented. The model is aimed to simulate complex non-mechanical and mechanical processes before and after depassivation of steel reinforcement. It was implemented into a 3D FE code and its application and performance will be illustrated through several numerical examples for natural and accelerated corrosion.
\end{abstract}

Key words: concrete, durability mechanics, corrosion of reinforcement, numerical simulations

\section{Modeliranje korozije armature u betonu: prošlost, sadašnjost i budućnost}

\section{Sažetak}

U prvom je dijelu izlaganja ukratko dan pregled različitih modela za modeliranje korozije armature $u$ betonskim konstrukcijama uzrokovane agresivnim djelovanjem klorida. Nakon toga je prikazan spregnuti tzv. 3D kemo-higro-termo-mehanički model za beton. Cilj je modela simulirati složene mehaničke i nemehaničke (transportne) procese prije depasivacije čelične armature i nakon nje. Model je implementiran u 3D FE program za nelinearnu analizu betonskih konstukcija, a njegova primjena i performanse prikazani su na nekoliko numeričkih primjera za slučajeve prirodne i ubrzane korozije.

Ključne riječi: beton, mehanika trajnosti, korozija armature, numerička simulacija 


\section{Introduction}

Durability of reinforced concrete structures is mainly influenced by the corrosion of steel reinforcement. Especially vulnerable are structures exposed to harsh sea climate conditions or highways and garages treated with de-icing salts during winter seasons [1]. Reinforcement corrosion can be initiated by: (i) the carbonation of the concrete and (ii) the penetration of chlorides from de-icing or sea salts. Both processes can destroy the inherent, thin, corrosion-protective oxide layer of the steel embedded in the concrete. After destruction of this oxide layer (depassivation), the so-called active corrosion phase, in which the steel is gradually converted into corrosion products (rust), initiates. The resulting consequences are: (i) reduction of the steel cross section by conversion of iron into iron oxides, (ii) cracking and possibly spalling of concrete cover due to the increasing the volume of the corrosion products in relation to the steel and (iii) reducing the bond strength between reinforcement bar and concrete. Consequences, durability, failure capacity and ductility of concrete structure can be significantly reduced.

In addition to the macro-cell corrosion of the steel reinforcement, in the case of chloride-induced corrosion the local (pitting) corrosion also occurs [2]. This type of corrosion is particularly dangerous as it causes local damage resulting in a large decrease in ductility and reduction of the cross-section of the reinforcing steel bar. The chemical processes leading to the pitting corrosion of steel reinforcement in concrete are known. However, only a few numerical studies exist at present. The main reason for this is high complexity of the processes, for which the relevant parameters are very difficult to determinate. This type of corrosion is decisive for the decrease of ductility and reduction of the cross-section of reinforcement bars. It has significant influence on the safety of reinforced and pre-stressed concrete structures. Therefore, the existing macro-model needs to be further extended, so that the pitting corrosion can also be simulated. Using such model in combination with experimental tests the conditions that are responsible for the initiation and progression of pitting corrosion can be more effectively studied.

According to current research status, there is only one coupled 3D CHTM model capable of simulating all relevant non-mechanical and mechanical processes and their interaction. This model was developed at the Institute of Construction Materials, University of Stuttgart, and implemented into the 3D FE code [3][4][5]. Over the past years, the model has been calibrated, verified and further improved based on the extensive experimental tests [6]. In the following its theoretical background and application is presented. 


\section{Chemo-hygro-thermo-mechanical model for concrete}

The above mentioned 3D chemo-hygro-thermo-mechanical model couples the physical and electrochemical processes with the mechanical behavior of concrete (damage). In the model the transport of capillary water is described in terms of volume fraction of pore water in concrete by Richard's equation [7], based on the assumption that transport processes take place in aged concrete, i.e., the hydration of cement paste is completed:

$$
\frac{\partial \theta_{w}}{\partial t}=\nabla \cdot\left[D_{w}\left(\theta_{w}\right) \nabla \theta_{w}\right]
$$

where $\theta_{w}$ is volume fraction of pore water $\left(\mathrm{m}^{3}\right.$ of water $/ \mathrm{m}^{3}$ of concrete) and $D_{w}\left(\theta_{w}\right)$ is capillary water diffusion coefficient $\left(\mathrm{m}^{2} / \mathrm{s}\right)$ described as a strongly non-linear function of moisture content. Transport of chloride ions through a non-saturated concrete occurs as a result of convection, diffusion and physically and chemically binding by cement hydration product [4]:

$$
\begin{gathered}
\theta_{w} \frac{\partial C_{c}}{\partial t}=\nabla \cdot\left[\theta_{w} D_{c}\left(\theta_{w}, T\right) \nabla C_{c}\right]+D_{w}\left(\theta_{w}\right) \nabla \theta_{w} \nabla C_{c}-\frac{\partial C_{c b}}{\partial t} \\
\frac{\partial C_{c b}}{\partial t}=k_{r}\left(\alpha C_{c}-C_{c b}\right)
\end{gathered}
$$

where $C_{c}$ is concentration of free chloride dissolved in pore water $\left(\mathrm{kgCl}-/ \mathrm{m}^{3}\right.$ pore solution), $D_{c}\left(\theta_{w^{\prime}} T\right)$ is the effective chloride diffusion coefficient $\left(\mathrm{m}^{2} / \mathrm{s}\right)$ expressed as a function of water content and concrete temperature $T, C_{c b}$ is concentration of bound chloride ( $\mathrm{kgCl}-/ \mathrm{m}^{3}$ of concrete), $k_{r}$ is binding rate coefficient, $\alpha=0.7$ is constant [3].

Assuming that oxygen does not participate in any chemical reaction before depassivation of steel, transport of oxygen through concrete is considered as a convective diffusion problem:

$$
\theta_{w} \frac{\partial C_{o}}{\partial t}=\nabla \cdot\left[\theta_{w} D_{o}\left(\theta_{w}\right) \nabla C_{o}\right]+D_{w}\left(\theta_{w}\right) \nabla \theta_{w} \nabla C_{o}
$$

where $C_{o}$ is oxygen concentration in pore solution $\left(\mathrm{kg}\right.$ of oxygen $/ \mathrm{m}^{3}$ of pore solution) and $D_{o}\left(\theta_{w}\right)$ is the effective oxygen diffusion coefficient [3], dependent on concrete porosity $p_{\text {con }}$ and water saturation of concrete $S w$.

Based on the constitutive law for heat flow and conservation of energy, the equation which describes temperature distribution in continuum reads:

$$
\lambda \Delta T+W(T)-c \rho \frac{\partial T}{\partial t}=0
$$


where $\lambda$ is thermal conductivity $(\mathrm{W} /(\mathrm{m} \mathrm{K})), c$ is heat capacity per unit mass of concrete $(\mathrm{J} /(\mathrm{K} \mathrm{kg})), \rho$ is mass density of concrete $\left(\mathrm{kg} / \mathrm{m}^{3}\right)$ and $W$ is internal source of heating $\left(\mathrm{W} / \mathrm{m}^{3}\right)$. More detail related to the strong and weak formulations of the processes up to the depassivation of reinforcement can be found in Ožbolt et al. [3]. The corrosion of steel is activated with the depassivation of the steel reinforcement in concrete. The non-mechanical processes important for the propagation stage of steel corrosion in concrete are: (1) Mass sinks of oxygen at steel surface due to cathodic and anodic reaction, (2) The flow of electric current through pore solution and (3) The cathodic and anodic potential.

The oxygen consumption at the cathodic and anodic surfaces is a result of the following reactions of dissolved oxygen in the pore water with the electrons on the cathode:

$$
2 \mathrm{H}_{2} \mathrm{O}+\mathrm{O}_{2}+4 \mathrm{e}^{-} \rightarrow 4 \mathrm{OH}^{-}
$$

The transport of hydroxyl ions to the anode, where corrosion products forms:

$$
\begin{gathered}
\mathrm{Fe}^{2+}+2 \mathrm{OH}^{-} \rightarrow \mathrm{Fe}(\mathrm{OH})_{2} \\
4 \mathrm{Fe}(\mathrm{OH})_{2}+\mathrm{O}_{2}+2 \mathrm{H}_{2} \mathrm{O} \rightarrow 4 \mathrm{Fe}(\mathrm{OH})_{3}
\end{gathered}
$$

It can be calculated as:

$$
\begin{array}{ll}
\left.D_{o}\left(S_{w}, p_{\text {con }}\right) \frac{\partial C_{o}}{\partial n}\right|_{\text {cathode }}=-k_{c} i_{c} & k_{c}=8.29 \times 10^{-8} \frac{\mathrm{kg}}{\mathrm{C}} \\
\left.D_{o}\left(S_{w}, p_{\text {con }}\right) \frac{\partial C_{o}}{\partial n}\right|_{\text {anode }}=-k_{a} i_{a} & k_{a}=4.14 \times 10^{-8} \frac{\mathrm{kg}}{\mathrm{C}}
\end{array}
$$

where $n$ is outward normal to the steel bar surface and $i_{c}$ and $i_{a}$ are cathodic and anodic current density $\left(\mathrm{A} / \mathrm{m}^{2}\right)$, respectively. The constants $k_{c}$ and $k_{a}$ are calculated using the stoichiometry of chemical reactions (Eqs. 5-7) and Faraday's law.

According to Butler - Volmer kinetics, in the present model kinetics of reaction at the cathodic and anodic surface can be estimated from:

$$
i_{c}=i_{0 c} \frac{C_{o}}{C_{o b}} e^{2.3\left(\Phi_{0 c}-\Phi\right) / \beta_{c}} \quad \quad i_{a}=i_{0 a} e^{2.3\left(\Phi-\Phi_{0 a}\right) / \beta_{a}}
$$


where $C_{o b}$ is oxygen concentration at surface of concrete element exposed to sea water $\left(\mathrm{kg} / \mathrm{m}^{3}\right), \Phi$ is electric potential in pore solution near reinforcement surface $(\mathrm{V}), i_{0 c}$ and $i_{0 a}$ are the exchange current density of the cathodic and anodic reaction $\left(\mathrm{A} / \mathrm{m}^{2}\right), \Phi_{0 c}$ and $\Phi_{0 a}$ are the cathodic and anodic equilibrium potential (V), $\beta_{c}$ and $\beta_{a}$ are the Tafel slope for cathodic and anodic reaction $(\mathrm{V} / \mathrm{dec})$, respectively.

The electric current through the electrolyte is a result of motion of charged particles and, if the electrical neutrality of the system and the uniform ions concentration are assumed, can be written as:

$$
\mathbf{i}=-\sigma\left(S_{w,} p_{c o n}\right) \nabla \Phi
$$

where $\sigma$ is electrical conductivity of concrete. The equation of electrical charge conservation, if the electrical neutrality is accounted for and the electrical conductivity of concrete is assumed as uniformly distributed, reads:

$$
\nabla^{2} \Phi=0
$$

Rate of rust production $J_{r}\left(\mathrm{~kg} / \mathrm{m}^{2} \mathrm{~s}\right)$ and mass of hydrated red rust per related surface $\left(A_{r}\right)$ of rebar $m_{r}(\mathrm{~kg})$, respectively, are calculated as:

$$
\begin{aligned}
& J_{r}=5.536 \times 10^{-7} i_{a} \\
& m_{r}=J_{r} \Delta t A_{r}
\end{aligned}
$$

where $\Delta t$ is time interval in which the corrosion is taking place. The coefficient of proportionality between the anodic current density $i_{r}$ and rate of rust production $J_{r}$ is calculated using the stoichiometry of chemical reactions and Faraday's law [4]. The distribution of corrosion product (red rust) $R\left(\mathrm{~kg} / \mathrm{m}^{3}\right.$ of pore solution) into the pores and through the cracks in concrete has been mathematically formulated as a convective diffusion problem:

$$
\theta_{w} \frac{\partial R}{\partial t}=\nabla \cdot\left[\theta_{w} D_{r} \nabla R\right]+D_{w}\left(\theta_{w}\right) \nabla \theta_{w} \nabla R
$$

in which $D_{r}$ is the diffusion coefficient $\left(\mathrm{m}^{2} / \mathrm{s}\right)$ of corrosion product. It is important to note that the Eq. (13) does not directly describe the transport of the red rust, but rather the distribution of the rust formed in the concrete pores and cracks as a consequence of soluble species, which can dissolve in concrete pore solution and subsequently migrate in pores and cracks, reacting with oxygen in the pore water 
[8]. Detailed experimental and numerical investigations have been carried out recently in order to calibrate the present model with this respect [6].

The microplane model for concrete with relaxed kinematic constraints [5] is applied in the mechanical part of the model. One-dimensional corrosion contact elements are employed in the model to account for the inelastic strains due to the expansion of corrosion products. They are placed radially around the bar surface and their main function is to simulate the contact between reinforcement and the surrounding concrete. These contact elements can take up only shear forces in direction parallel to reinforcement axis and compressive forces perpendicular to the adjacent surface of the reinforcement. The inelastic radial expansion due to corrosion $\Delta \mathrm{l}_{r}$ is calculated as:

$$
\Delta l_{r}=\frac{m_{r}}{A_{r}}\left(\frac{1}{\rho_{r}}-\frac{0.523}{\rho_{s}}\right)
$$

where $\rho_{r}=1.96 \times 103\left(\mathrm{~kg} / \mathrm{m}^{3}\right)$ and $\rho_{s}=7.89 \times 103\left(\mathrm{~kg} / \mathrm{m}^{3}\right)$ are densities of rust and steel, respectively, 0.523 is the ratio between the mass of steel $\left(m_{s}\right)$ and the corresponding mass of rust $\left(m_{r}\right)$ over the related surface of reinforcement $A_{r}$ that corresponds to the contact element. For more detail see [3] [4].

\section{Numerical case study}

The application of the presented 3D CHTM model is here demonstrated through numerical study of the pull-out of the reinforcement bar from a beam-end specimen. The specimen is first exposed to aggressive environmental conditions, which caused corrosion of embedded reinforcement bar. Subsequently the bar is pulled out from the specimen and for the different levels of corrosion the numerical results are compared with the test results obtained by Fischer at al. [9]. The experiments were carried out under accelerated corrosion, which approximately corresponds to the severe splash natural conditions.

Only two specimen types with four bars arranged in corners are studied. In the first specimen type, the diameter of the reinforcement bar is $12 \mathrm{~mm}$ with a concrete cover of $20 \mathrm{~mm}(\phi 12 / 20 \mathrm{~mm})$ and in the second, the bar diameter of $16 \mathrm{~mm}$ with a cover of $35 \mathrm{~mm}(\phi 16 / 35 \mathrm{~mm})$ is used. The total embedment length of the reinforcement in both cases is $180 \mathrm{~mm}$, whereas the rest of the length is isolated with a plastic sleeve (Figure 1). For more detail see [5] [9]. 
Longitudinal cross section

300
$\leftarrow 120 \nmid \quad 180 \leftarrow$
$\leftarrow$

a)

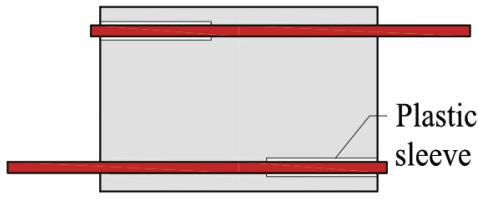

Cross section $ø 12 / 20 \mathrm{~mm}$
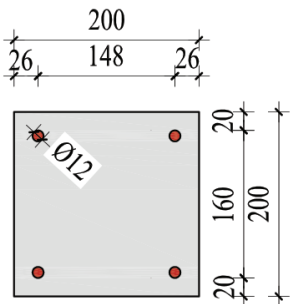

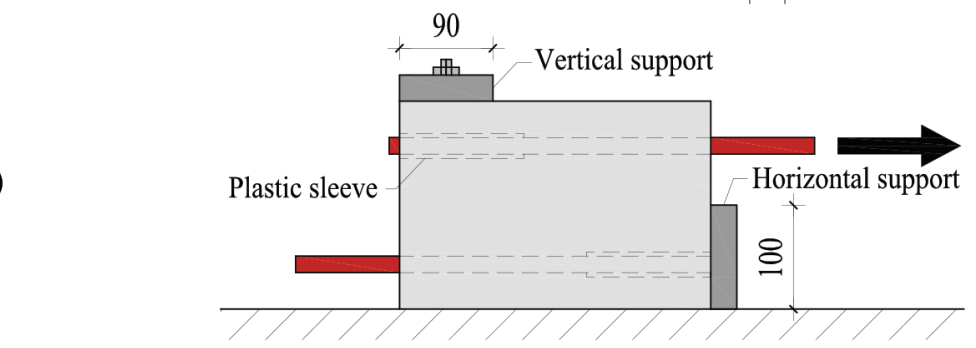

Cross section $ø 16 / 35 \mathrm{~mm}$
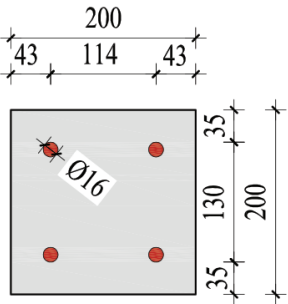

b)

Figure 1. a) Geometry of the beam-end specimen, b) and pull-out loading condition (Fischer et al. [9])

In the analysis is assumed that certain length sections of the bar are activated as anode (depassivated) at the start of the analysis, i.e. the processes before depassivation of reinforcement are not computed. This predefined position of anode and cathode (Figure 2a), assuming initially un-cracked concrete, is kept unchanged during the computation. In this way after depassivation only the electric potential, current density, distribution of oxygen and cracking of concrete are calculated. More detail related to the position and size of anodic and chatodic areas can be found in [10].

One of the aims of the study was to investigate the influence of the position of anode along the cross-section of the bar reinforcement. Therefore for each specimen (reinforcement diameter) three configurations of the anodic surface over the circumference are assumed (see Figure $2 b$ ).

a)

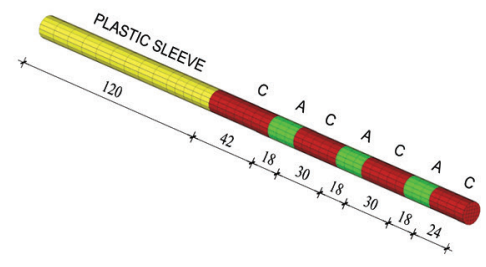

b)

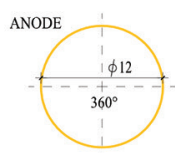

$1 \mathrm{~A}$

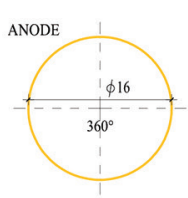

2A

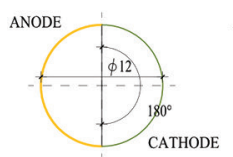

$1 B$

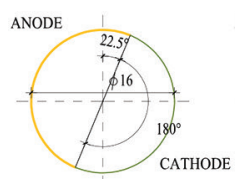

2B

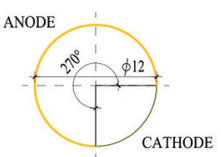

$1 \mathrm{C}$

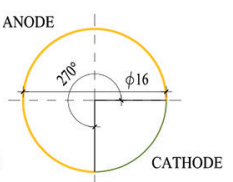

2C

Figure 2. Assumed anodic and cathodic regions: a) along the length, b) along the cross-section of the reinforcement bar 


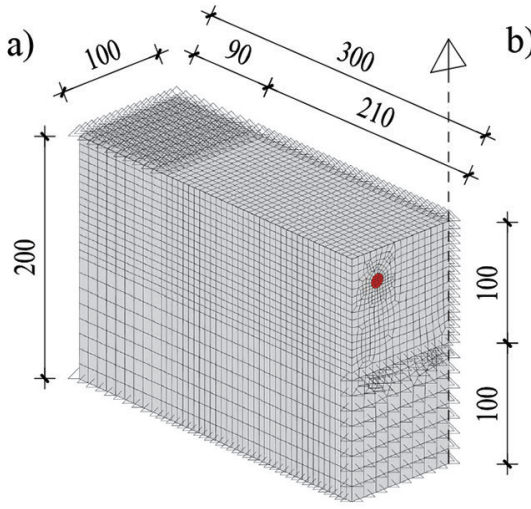

b) $\tau\left[\mathrm{N} / \mathrm{mm}^{2}\right]$

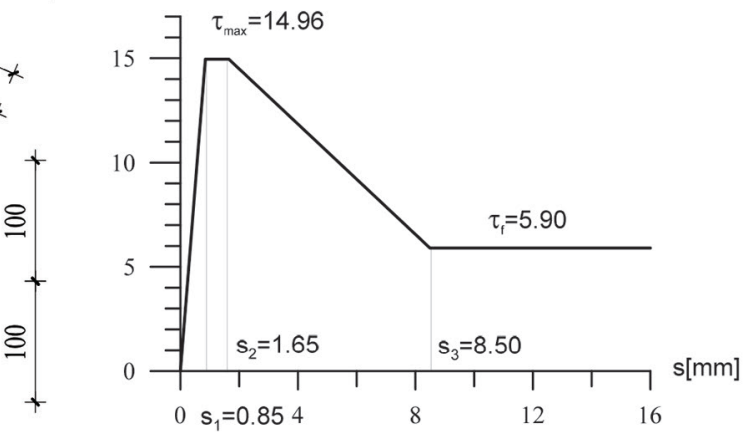

Figure 3. Model geometry (all in $\mathrm{mm}$ ) in the case of: a) the first and b) the second specimen

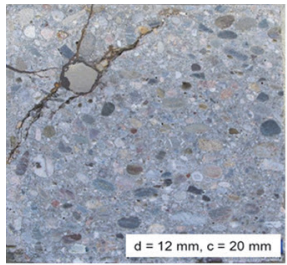

Fischer at al. [9]

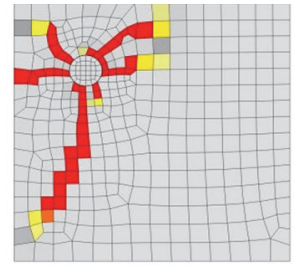

$1 \mathrm{~A}$

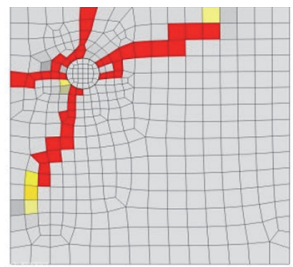

1B

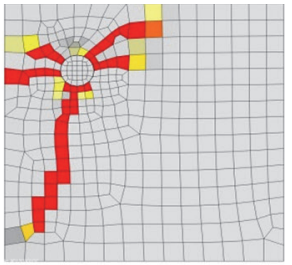

$1 \mathrm{C}$

Figure 4. Comparison of the crack patterns in the cross section at the beam's mid-span for the cases $1 \mathrm{~A}-\mathrm{C}$ with the experimental results

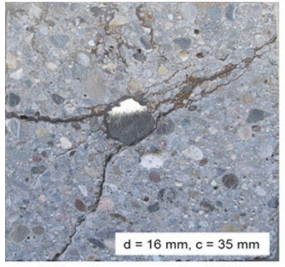

Fischer et al. [9]

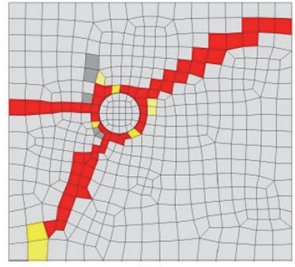

$2 \mathrm{~A}$

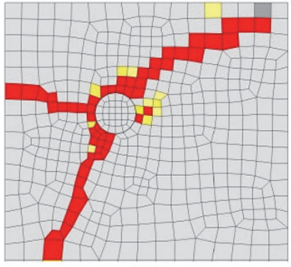

2B

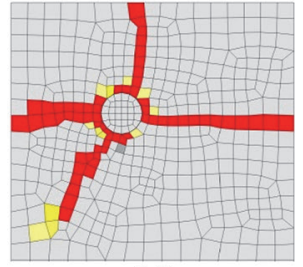

$2 \mathrm{C}$

Figure 5. Comparison of the crack patterns in the cross section at the beam's mid-span for the cases $2 \mathrm{~A}-\mathrm{C}$ with the experimental results

Because of the complexity of the model and in order to reduce the computational time only half of the specimen is modeled (Figure 3a). Eight-node solid 3D finite elements are used to model the concrete and the reinforcement bar. To simulate the expansion due to the formation of corrosion products, 1D radially oriented corrosion contact finite elements are used with a length of $0.1 \mathrm{~mm}$. These elements can take up radial forces (only compressive) and shear forces in direction of reinforcement axis (see Figure 3b). Experimentally observed and 
numerically predicted crack patterns in the mid cross section of the specimen, 7 years after depassivation of reinforcement, are shown in Figure 4 and Figure 5 . For the first specimen $(\phi 12 / 20 \mathrm{~mm})$ the position of anode $1 \mathrm{~A}$ and $1 \mathrm{C}$ leads to a similar crack formation around the reinforcement bar, whereas type $1 \mathrm{~B}$ gives better agreement with the experimental crack pattern. For the type 2 , the case $2 \mathrm{~B}$ leads to the best agreement with the test data. The above presented results show that the position of cathode and anode in the case 1B for the first specimen $(\phi 12 / 20 \mathrm{~mm})$ gives the best agreement with the experimental results. Therefore this case is chosen to demonstrate the effect of distribution of corrosion products over the cracks. Two cases are considered: (a) transport of rust is neglected and (b) transport is accounted for. The same as before, for each case the beams are exposed to the corrosion processes over the period of 7 years. The damage (cracking) due to the expansion of corrosion products after 1 and 7 years, respectively, for the type $1 \mathrm{~B}$ is shown in Figure 6 . The numerical results indicate a significant influence of the rust distribution on the corrosion induced damage for the here studied type of chloride induced corrosion, with relatively high saturation.

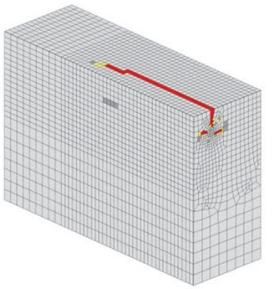

$1 \mathrm{y}$, no transport

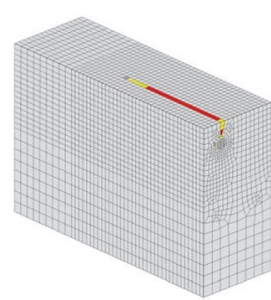

$1 \mathrm{y}$, with transport

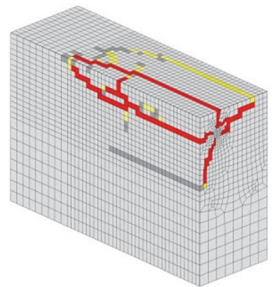

$7 \mathrm{y}$, no transport

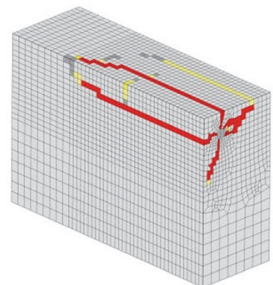

$7 \mathrm{y}$, with transport

Figure 6. Predicted crack patterns due to corrosion induced damage after 1 and 7 years for specimen type 1B
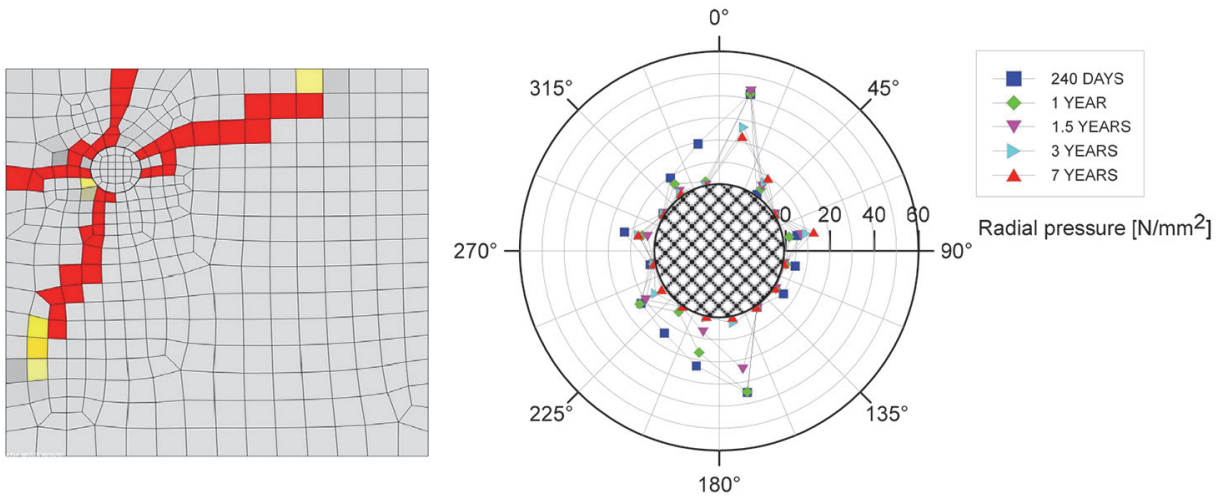

Figure. 7. Distribution of radial pressure and corresponding crack patterns 
In Figure 7 the distribution of radial pressure as a consequence of expansion of corrosion products is plotted for the case 1B. The pressure is shown in the anode-cathode transition zone. As expected, the pressure is not axial symmetrically distributed over the surface of reinforcement. The maximum radial pressure of approximately $40 \mathrm{MPa}$ is observed and it is obtained approximately 1.5 years after the start of the corrosion phase.

After depassivation of reinforcement (corrosion phase), among other parameters, the corrosion rate is strongly influenced by distribution of water and oxygen. For instance, if the supply of oxygen is not sufficient the corrosion process will stop. In the present numerical investigations the water saturation is assumed to be constant during the corrosion phase $\left(S_{w}=50 \%\right)$. However, the distribution of oxygen depends on the corrosion rate, which is in turn dependent on the mechanical properties of concrete (cracking). More cracking causes better oxygen supply and consequently leads to higher corrosion rate.

The distribution of electric potential $(\mathrm{V})$, current density $\left(\mathrm{A} / \mathrm{m}^{2}\right)$ and oxygen $(\mathrm{kg} /$ $\mathrm{m}^{3}$ of pore solution) along $162 \mathrm{~mm}$ length of the reinforcement bar, starting from the pull-out surface, are shown in Figure 8. Plotted are average values over the corresponding cathodic and anodic cross-section of the bar. The distributions of the current density and electric potential along the length of the bar show that the highest electric potential and current density is predicted in the cathode-anode transition zone.

The distribution of oxygen concentration along the reinforcement bar is shown in Figure 9. It demonstrates significant effect of the corrosion induced damage and the importance of coupling of transport processes with mechanical properties of concrete. The consumption of oxygen reaches its maximum soon after the start of the analysis (depassivation) and remains approximately constant until the first surface crack appears. With the opening of the surface crack(s) the flow of oxygen rises and consequently the concentration of oxygen at the reinforcement surface 7 years after depassivation is almost identical as at the beginning of the corrosion process.

a)

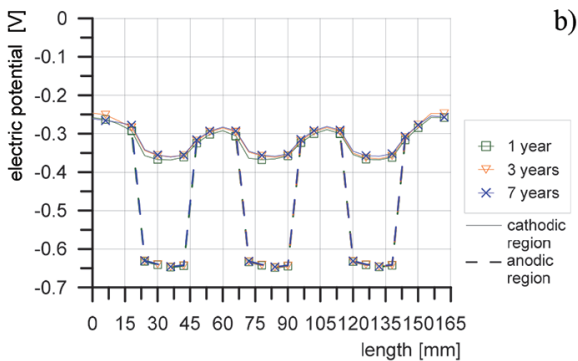

b)

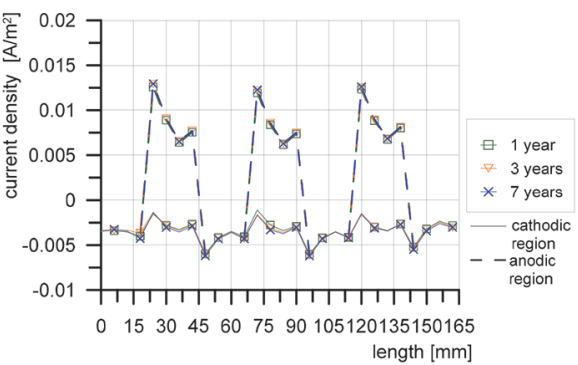

Figure 8. Average distribution of: a) electric potential, b) current density over the reinforcement length for the specimen type 1B 
a)

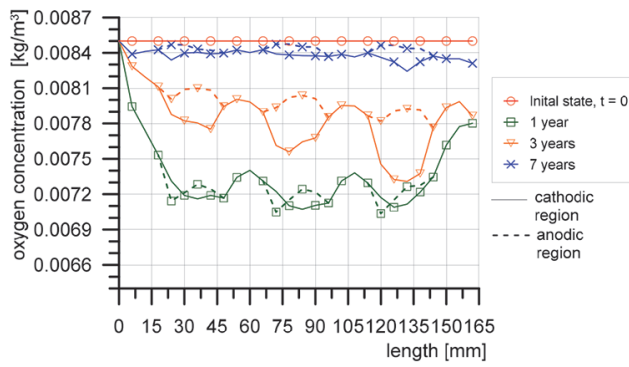

b)

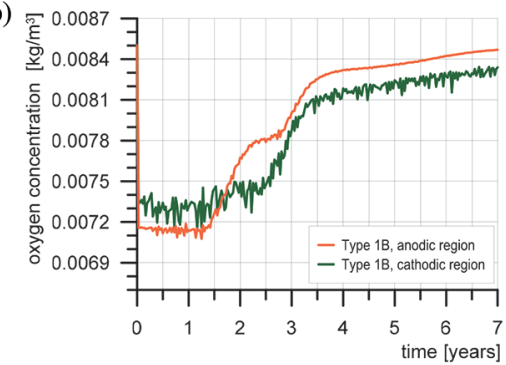

Figure 9. The distribution of average oxygen concentration for the specimen type 1B: a) over the bar length, $b$ ) in the the time (length position $=24 \mathrm{~mm}$ )

From Figure 9a can be seen that the anodic and cathodic regions of the same bar cross sections exhibit a different rate of oxygen concentration change. This is clearly shown in Figure 9b where the average cathode and anode oxygen concentration is plotted as a function of time for $1 \mathrm{~B}$ case, in the cross-section of the anode-cathode transition zone at $24 \mathrm{~mm}$ distance from the pull-out surface of the specimen. The anodic region shows a higher consumption of oxygen at the beginning of the corrosion process. Due to the accumulation of the corrosion products in this area which caused damage, the effect of cracking on oxygen distribution is faster compared to the cathodic regions. These areas (cathode) are further away from the cracked concrete elements and therefore the increased ingress of oxygen through the cracks is being manifested more slowly.

To demonstrate the influence of corrosion products transport through cracks on bond resistance, the reinforcement bar is pulled out from the concrete specimens (type 1B) at $t=0$ (reference), 1, 2, 3, 4, 5 and 7 years, respectively. The predicted and experimentally measured (average) pull-out capacities and average crack widths are shown in Figure 10 as a function average corrosion penetration. In spite of high complexity of the problem, it can be seen that for both specimen types the numerical prediction, for the case where the transport of corrosion products is accounted for, exhibits nice agreement with the experimental data.

a)

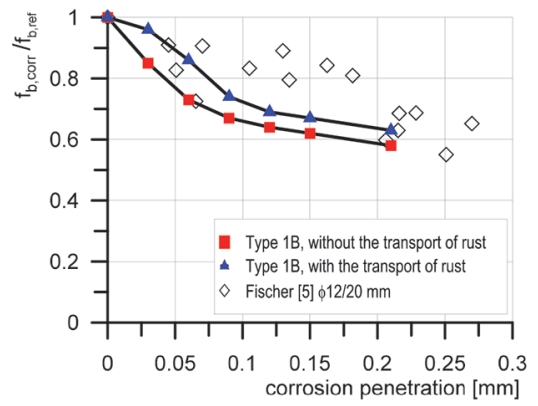

b)

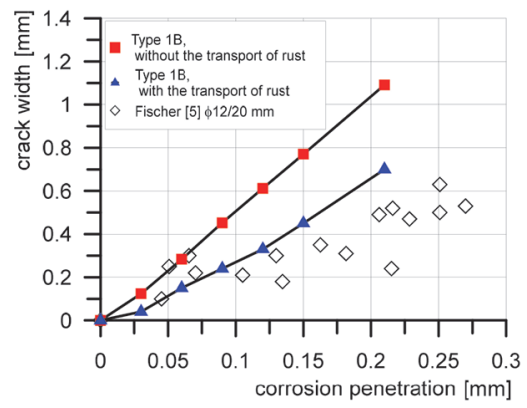

Figure 10. Predicted and measured results for specimen 1B: a) The relative pull-out capacity as a function of the average corrosion penetration, b) average crack width as a function of the average corrosion penetration 


\section{Conclusions}

The coupled 3D CHTM model for analysis of non-mechanical and mechanical processes related to the corrosion of steel reinforcement in concrete is briefly discussed. The application of the model is demonstrated through the example of corroded steel reinforcement that is pulled out from the concrete beam-end specimen. For the assumed environmental conditions and material properties it is shown that the predicted corrosion induced crack pattern depends on the geometry (bar diameter and concrete cover), position of anode and cathode and on the transport of corrosion products through cracks. As the results of numerical analysis show, corrosion induced damage significantly reduces the pull-out capacity. The predicted and experimentally measured pull-out capacity show very good agreement. Moreover, it is shown that during the active corrosion phase the corrosion rate depends on corrosion induced damage and transport of corrosion products through cracks.

\section{References}

[1] Tutti K 1993 Corrosion of steel in concrete Technical report Stockholm.

[2] Oldham KB, Myland JC and Bond M 2012 Electrochemical Science and Technology -Fundamentals and Applications John Wiley \& Sons Ltd.

[3] Ožbolt J, Balabanić G, Periškić G and Kušter M 2010 Modelling the effect of damage on transport processes in concrete Constr. Build. Mater. 24 (9) 1638-1648.

[4] Ožbolt J, Balabanić G and Kušter M 2011 3D Numerical modelling of steel corrosion in concrete structures, Corrosion Science 53 4166-4177.

[5] Ožbolt J, Oršanić F and Balabanić G 2014 Modeling pull-out resistance of corroded reinforcement in concrete: Coupled three-dimensional finite element model Cement and Concrete Composites 46 41-55.

[6] Sola E, Ožbolt J, Balabanić G and Mir ZM 2019 Experimental and numerical study of accelerated corrosion of steel reinforcement in concrete: Transport of corrosion products Cement and Concrete Research 120 119-131.

[7] Bear J and Bachmat $Y 1991$ Introduction to modeling of transport phenomena in porous media Boston: Kluwer Academic Publishers.

[8] Wong HS, Zhao YX, Karimi AR, Buenfeld NR and Jin WL 2010 On the penetration of corrosion products from reinforcing steel into concrete due to chloride-induced corrosion Corros. Sci. 2(7) 2469-2480. 
[9] Fischer C, Ožbolt J and Gehlen C 2012 Verbundfestigkeit von korrodierter Bewehrung, in: Dauerhaftigkeitsbemessung von Stahlbetonbauteilen auf Bewehrungskorrosion Teil 2: Dauerhaftigkeitsbemessung Berlin: Beuth (Deutscher Ausschuss für Stahlbeton 602) 47-88.

[10] Ožbolt J, Balabanić G and Sola E 2017 Determination of critical anodic and chathodic areas in corrosion processes of steel reinforcement in concrete Materials and Corrosion 68(6). 